\title{
BADANIE WPEYWU DODATKU ZMIENNOFAZOWEGO NA WŁAŚCIWOŚCI CIEPLNE WYBRANEGO MATERIAŁU BUDOWLANEGO
}

\begin{abstract}
Istotną cechą obecnego budownictwa jest stosowanie lekkiej konstrukcji oraz większych powierzchni oszklonych, co prowadzi do przegrzania lub wychłodzenia budynków, w zależności od warunków atmosferycznych. Z drugiej strony, mieszkańcy budynków spędzają znaczną część czasu w pomieszczeniach zamkniętych, w wyniku czego wzrasta zużycie energii do celów chłodniczych lub grzewczych. Rozwiązaniem tego problemu może być zastosowanie w konstrukcji budynku materiału budowlanego zmieszanego z materiałem zmiennofazowym (PCM), który przechowuje energię $\mathrm{w}$ formie utajonej, w procesie przemiany fazowej topnienia lub krzepnięcia. Powszechnie wiadomo, że właściwości termofizyczne materiałów budowlanych będą miały wpływ na zużycie energii w budynku. W związku z tym interesujące jest zbadanie nie tylko możliwości wykorzystania PCM-u jako materiału zwiększającego pojemność cieplną, ale i jego wpływu na właściwości cieplne, takie jak przewodność cieplna materiału budowlanego. W pracy wyznaczono współczynnik przewodzenia ciepła mieszaniny tynku gipsowego i organicznego materiału zmiennofazowego.
\end{abstract}

Słowa kluczowe: wymiana ciepła, tynk gipsowy, przewodzenie ciepła

\section{Wstęp}

Pomysł wykorzystania materiałów zmiennofazowych w konstrukcjach budowlanych pojawił się w literaturze już w latach 80. [2]. Materiały zmiennofazowe (PCM - Phase Change Materials) wydają się być jedną z najbardziej obiecujących metod zwiększenia pojemności cieplnej lekkich konstrukcji budowlanych. Zaletą tego typu materiałów może być wysoka gęstość magazynowanej energii cieplnej na jednostkę objętości, tzw. ciepło utajone, która jest pobierana lub oddawana $w$ procesie przemiany fazowej (topnienia lub krzepnięcia), w małym przedziale temperatury. Energia ta jest wielokrotnie większa w obszarze temperatury przejścia fazowego w stosunku do ciepła właściwego

\footnotetext{
${ }^{1}$ Autor do korespondencji/corresponding author: Ewa Skawińska, Politechnika Wrocławska, ul. Wybrzeże Wyspiańskiego 27, 50-370 Wrocław, tel.: (71) 3203091, e-mail: ewa.skawinska@pwr.edu.pl.
} 
materiału budowlanego. Zbadano wiele substancji w charakterze materiału zmiennofazowego. Następnie podzielono je na trzy kategorie: związki organiczne (stałe węglowodory, kwasy tłuszczowe), związki nieorganiczne (hydraty soli, metale) i mieszaniny eutektyczne [3].

W niniejszej pracy przedstawiono wstępne wyniki badań nad wpływem ilości materiału PCM typu stałego węglowodoru w mieszaninie $\mathrm{z}$ tynkiem gipsowym na współczynnik przewodzenia ciepła.

\section{Eksperyment}

W badaniach wykorzystano tynk gipsowy firmy Knauf, który w Polsce jest materiałem budowlanym powszechnie stosowanym jako wewnętrzna warstwa ścian. Gęstość nasypowa tynku gipsowego wynosi ok. $900 \mathrm{~kg} / \mathrm{m}^{3}$. Jako materiał zmiennofazowy dodawano do tynku gipsowego handlowy produkt o nazwie PX 27, wyprodukowany przez Rubitherm GmbH. Postać handlową stanowi 60\% wagowych stałego węglowodoru na krzemionce jako nośniku. Właściwości termofizyczne materiału zmiennofazowego PX 27 zestawiono w tab. 1.

Tabela 1. Właściwości termofizyczne materiału zmiennofazowego PX 27 (na podstawie [6])

Table 1. Thermo-physical properties of the phase change material PX 27 (on the basis of [6])

\begin{tabular}{|l|c|}
\hline \multicolumn{1}{|c|}{ Właściwości termofizyczne } & PX 27 \\
\hline Temperatura topnienia, ${ }^{\circ} \mathrm{C}$ & $25-28$ \\
Temperatura krzepnięcia, ${ }^{\circ} \mathrm{C}$ & $28-25$ \\
Ciepło przemiany fazowej, $\mathrm{kJ} / \mathrm{kg}$ & 102 \\
Gęstość objętościowa, $\mathrm{kg} / \mathrm{dm}^{3}$ & 0,65 \\
Współczynnik przewodzenia ciepła, $\mathrm{W} /(\mathrm{m} \cdot \mathrm{K})$ & 0,20 \\
\hline
\end{tabular}

W celu pomiaru współczynnika przewodzenia ciepła przygotowanych próbek materiału budowlanego (tynku gipsowego) z różnym udziałem wagowym materiału zmiennofazowego zaprojektowano stanowisko pomiarowe. Pomiar współczynnika oparto na metodzie ustalonego przekazywania ciepła [5]. $\mathrm{W}$ związku z tym, że przeważającym materiałem w mieszaninie (PCM - tynk gipsowy) jest materiał budowlany, projekt stanowiska oparto na aparacie płytowym opisanym w normie ISO 8302. Układ pomiarowy został tak zaprojektowany, aby współczynnik przewodzenia ciepła mógł być wyznaczany dla różnych materiałów w zwartej formie. Schemat ideowy stanowiska przedstawiono na rys. 1.

Zaprojektowane stanowisko jest przeznaczone do wytwarzania wewnątrz próbki w kształcie walca o średnicy $150 \mathrm{~mm}$ i równoległych powierzchniach, 
jednokierunkowego strumienia ciepła o stałej gęstości w warunkach stanu ustalonego. Kształt walca wybrano ze względu na uniknięcie mostków termicznych.

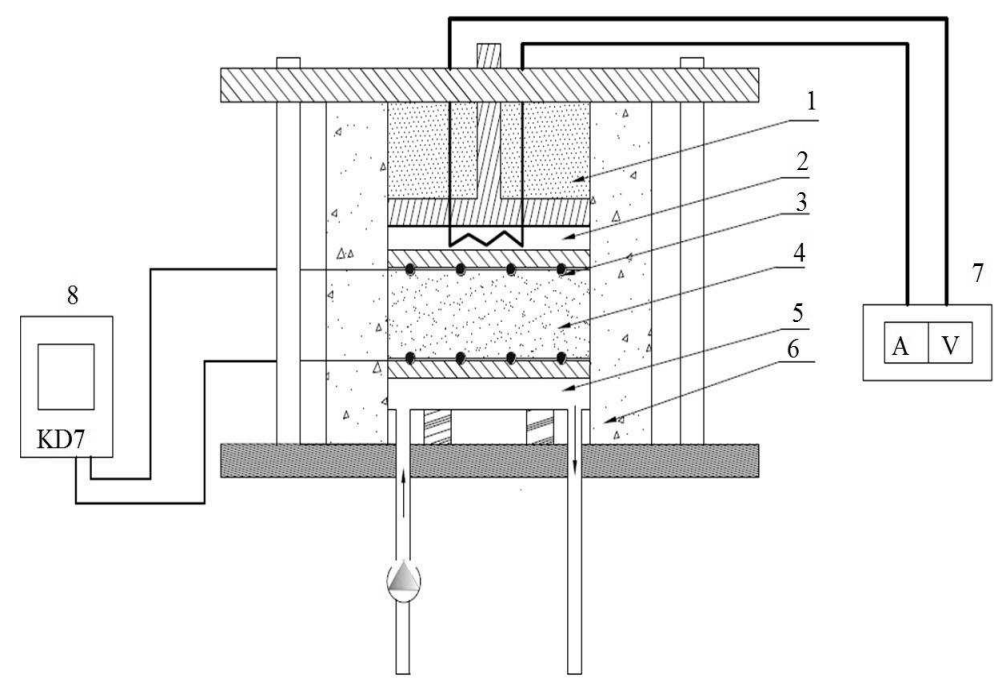

Rys. 1. Schemat stanowiska pomiarowego współczynnika przewodzenia ciepła dla próbki materiału budowlanego; 1 - izolacja $\mathrm{z}$ wełny mineralnej, 2 - płaska grzałka, 3 - termoelementy, 4 - próbka, 5 - wymiennik ciepła, 6 - izolacja styropianowa, 7 - autotransformator, 8 - rejestrator temperatury

Fig. 1. Scheme of measuring position of the thermal conductivity for a sample of building material; 1 - mineral wool insulation, 2 - flat heater, 3 - thermocouples, 4 - the sample, 5 - heat exchanger, 6 - outer polystyrene insulation, 7 - autotransformer, 8 - temperature recorder

Wymiana ciepła jest wymuszona przez dwie płaskie izotermiczne powierzchnie styczne do powierzchni próbki, nazywane dalej zespołem grzejnym i chłodzącym. W celu zapewnienia dobrego kontaktu cieplnego oraz dokładnej odległości między płytami aparatu zastosowano układ stałej siły dociskowej. Stanowisko pomiarowe jest zaizolowane i umieszczone w pomieszczeniu z możliwością kontrolowania temperatury otoczenia [4]. Ze względu na to, że nie jest możliwe idealne zaizolowanie układu, przed rozpoczęciem wykonywania pomiaru przewodnictwa cieplnego próbki określono straty cieplne. Badania rzeczywistego strumienia ciepła dostarczonego do układu pomiarowego wykonano za pomocą modelowej próbki wykonanej z polimetakrylanu metylu (PMMA) o znanym współczynniku przewodzenia ciepła, równym $0,18 \mathrm{~W} /(\mathrm{m} \cdot \mathrm{K})$ [1]. Otrzymane wyniki umożliwiły określenie strat cieplnych w funkcji mocy dostarczonej do układu grzejnego.

Za pomocą termopar mierzono temperaturę próbki w czterech miejscach każdej ze stron (grzejnej i chłodzącej), do osiągnięcia stanu równowagi. Obliczenia opierały się na następujących założeniach: 
1) wymiana ciepła w kierunku promieniowym przez próbkę jest pomijalna w związku z dobrze zaizolowanym układem,

2) straty pomiędzy powierzchnią grzejną a otoczeniem zostały wyznaczone w oddzielnym doświadczeniu,

3) próbka jest traktowana jak ciało jednorodne.

Opierając się na określonych założeniach, zastosowano jednowymiarowe prawo Fouriera:

$$
\dot{q}=-\lambda(T) \frac{\mathrm{d} T}{\mathrm{~d} x}
$$

gdzie: $\dot{q}$ - gęstość strumienia ciepła,

$\lambda$ - współczynnik przewodzenia ciepła.

Założono, że strumień ciepła dostarczony do próbki jest stały. Temperaturę powierzchni przyjęto jako średnią arytmetyczną poszczególnych wartości zmierzonych:

$$
\begin{gathered}
\bar{T}_{c h}=\frac{T_{1}+T_{2}+T_{3}+T_{4}}{4} \\
\bar{T}_{g}=\frac{T_{5}+T_{6}+T_{7}+T_{8}}{4}
\end{gathered}
$$

gdzie: $T_{1}-T_{8}-$ zmierzone temperatury,

$\bar{T}_{c h}$ - średnia temperatura w zespole chłodzącym,

$\bar{T}_{g}$ - średnia temperatura w zespole grzejnym.

Opierając się na równaniu (1) i znając średnie temperatury w zespole grzejnym i chłodzącym oraz moc dostarczoną do układu, a także wymiary mierzonej próbki, wyznaczono współczynnik przewodzenia ciepła próbki $\lambda$, korzystając $\mathrm{z}$ równania:

$$
\lambda(T)=\frac{Q \cdot \delta}{A \cdot\left(\bar{T}_{g}-\bar{T}_{c h}\right)}
$$

gdzie: $A$ - powierzchnia próbki,

$Q$ - moc wejściowa z zasilacza laboratoryjnego pomniejszona o wyznaczone straty,

$\delta$ - grubość próbki.

Na rysunku 2. przedstawiono otrzymane wartości współczynnika przewodzenia ciepła $\lambda$, obliczone ze wzoru (4) na podstawie zmierzonych temperatur dla dwóch próbek. Skład próbki otrzymanej z mieszaniny tynku gipsowego 
- PCM został określony na podstawie udziału wagowego suchych składników. Zmiany temperatury (w badanym zakresie) mają niewielki wpływ na zmianę przewodności cieplnej tynku gipsowego. Wartość oscyluje wokół linii prostej w granicach błędu pomiarowego. Z kolei w przypadku próbki będącej mieszaniną tynku gipsowego i materiału zmiennofazowego zaobserwowano zmiany wartości współczynnika przewodzenia w pobliżu temperatury topnienia węglowodoru, będącego składnikiem PCM-u (PX 27).

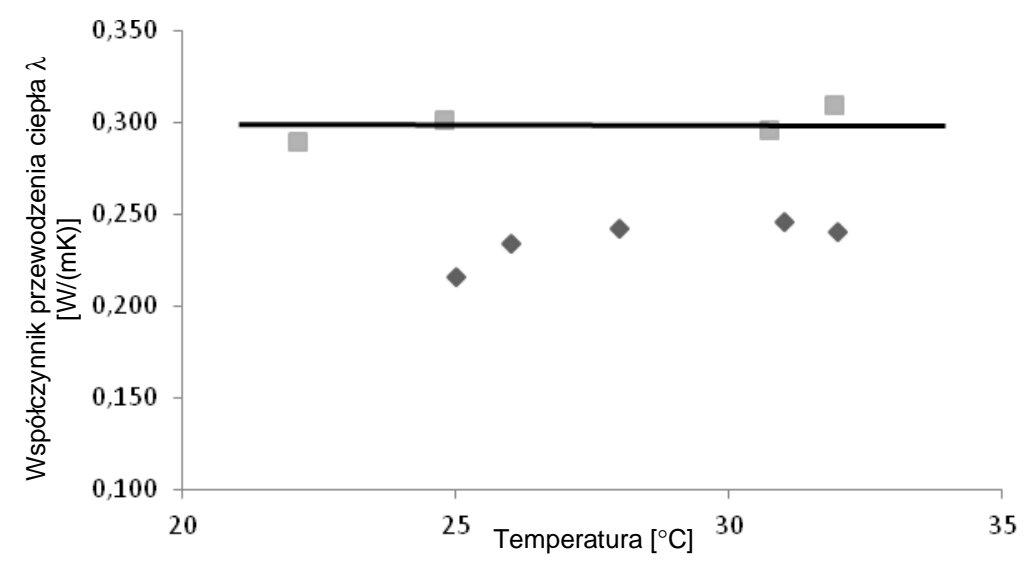

Rys. 2. Współczynnik przewodzenia ciepła próbek otrzymanych z tynku gipsowego (ロ) lub mieszaniny tynk gipsowy i 10\% PCM (PX 27) (^) w zależności od temperatury

Fig. 2. Thermal conductivity of samples obtained from gypsum plaster ( $\mathbf{a})$ or mixture of gypsum plaster and 10\% PCM (PX 27) ( $)$ at different temperature

Wyniki mogą wykazywać na duży wpływ materiału zmiennofazowego na przewodność cieplną powstałej mieszaniny. Współczynnik przewodności cieplnej tynku gipsowego $(\lambda=0,30 \pm 0,038 \mathrm{~W} /(\mathrm{m} \cdot \mathrm{K}))$ spada do wartości ok. $0,245 \pm 0,038 \mathrm{~W} /(\mathrm{m} \cdot \mathrm{K}) \mathrm{w}$ badanym zakresie temperatur. Wydaje się interesujące wykonanie pomiarów dla kilku różnych stężeń PCM-u (PX27) oraz zbadanie wpływu dodatku materiału zmiennofazowego na mechaniczne właściwości próbki laboratoryjnej materiału budowlanego.

\section{Podsumowanie}

Opracowano sposób preparacji próbek tynku otrzymanych z gipsu i mieszaniny gips-materiał zmiennofazowy. Zbudowano stanowisko do badania współczynnika przewodzenia ciepła materiałów budowlanych. Na podstawie otrzymanych wyników zaobserwowano, że wartość współczynnika przewodzenia ciepła próbki tynku otrzymanej z gipsu nie zmienia się w badanym zakresie temperatur $\left(20-35^{\circ} \mathrm{C}\right)$, natomiast próbka tynku otrzymana z mieszaniny gipsu 
i organicznego materiału zmiennofazowego (PX 27) wykazuje zmianę przewodnictwa cieplnego w pobliżu temperatury przemiany fazowej. Ponadto zauważono, że już niewielka ilość PCM-u (PX 27) obniża współczynnik przewodzenia ciepła, co pozwala przypuszczać, że tego typu materiały budowlane znajdą zastosowanie do budowy przegród budowlanych. Przeprowadzone badania są częścią większego projektu dotyczącego wykorzystania materiałów zmiennofazowych w konstrukcjach budowlanych oraz ich wpływu na współczynnik przewodzenia ciepła.

\title{
Literatura
}

[1] EN ISO 10456.

[2] Feldman D., Khan M.A., Banu D.: Energy storage composite with an organic PCM, Solar Energy Materials, 18 (1989), 333-341.

[3] Shazim A.M.: Phase change materials integrated in building walls: A state of the art review, Renew. Sust. Energy Rev., 31 (2014), 870-906.

[4] Skawińska E.: Badanie współczynnika przewodzenia ciepła w materiałach z dodatkiem PCM-ów, Zeszyty Energetyczne, Tom I. Problemy współczesnej energetyki, Oficyna Wydawnicza Politechniki Wrocławskiej, Wrocław 2014, s. 23-30.

[5] Stefański A.: Przewodność cieplna materiałów budowlanych, PWN, Warszawa 1965.

[6] www.rubitherm.com/2014.

\section{INVESTIGATION OF EFFECT OF PHASE CHANGE MATERIALS ADDITIVE ON THE THERMAL PROPERTIES OF SELECTED CONSTRUCTION MATERIAL}

\begin{abstract}
S u m m a r y
The important features of the present construction industry are lightweight design and large glazed surfaces. Those aspects may lead to either overheating or cooling the buildings according to the weather. On the other hand people tend to spend a lot of time in confined spaces what results in increased energy consumption for both heating and cooling purposes. A solution of this problem could be the use of phase change materials in the building constructions. These materials store energy in a latent form (constant temperature) in the melting and solidification processes. It is commonly known, that thermophysical properties of the construction materials have an impact on the energy consumption. Therefore, it is interesting to investigate not only the possibility of using PCM to increase the heat capacity, but also to study its effect on the properties such as the thermal conductivity of building materials. In this paper, the thermal conductivity for mixture of gypsum plaster and organic phase change material was determined.
\end{abstract}

Keywords: heat transfer, gypsum plaster, thermal conduction

DOI: $10.7862 / \mathrm{rm} .2015 .24$

Otrzymano/received: $14.09 .2014 \mathrm{r}$.

Zaakceptowano/accepted: 20.03.2015 r. 